\title{
A new species of Chalcoscirtus (Araneae: Salticidae) from Altai, South Siberia, Russia
}

\author{
Yuri M. Marusik, Alexander A. Fomichev \& Varpu Vahtera
}

Marusik, Y. M., Fomichev, A. A. \& Vahtera, V. 2018: A new species of Chalcoscirtus (Araneae: Salticidae) from Altai, South Siberia, Russia. - Entomol. Fennica 29: 39-48.

A new species, Chalcoscirtus sinevi sp. n., from the Altai Mountains (South Siberia) is described on the basis of both sexes. The new species is closely related to C. grishkanae Marusik, 1988 from North-Eastern Siberia and Transbaikalia, which is also illustrated. Molecular evidences supporting a separate species status of the new species are provided.

Y. M. Marusik, Institute for Biological Problems of the North RAS, Portovaya Str. 18, Magadan 685000, Russia; Department of Zoology \& Entomology, University of the Free State, Bloemfontein 9300, South Africa; E-mail: yurmar@mail.ru

A. A. Fomichev, Altai State University, Lenina Pr., 61, Barnaul, RF-656049, Russia; E-mail: a.fomichov@mail.ru

V. Vahtera, Biodiversity Unit, Zoological Museum, University of Turku, FI20014 Turku, Finland; E-mail: varpu.vahtera@utu.fi

Received 23 January 2017, accepted 24 May 2017

\section{Introduction}

Chalcoscirtus Bertkau, 1880 is a Holarctic Salticinae genus, which currently includes 45 species (World Spider Catalog 2017). The majority of the species occur in high mountains of Europe, Central Asia and Northeastern Siberia and most of them have very limited ranges (Marusik 1991b). Only four species are known from the Nearctic (Cutler 1990, Edwards 2003). This genus is well studied due to several revisional studies in the Nearctic (Cutler 1990), Central Asia and Caucasus (Logunov \& Marusik 1999) and in the Eastern Palaearctic (Marusik 1990, 1991a,b). Eleven species of Chalcoscirtus have been recorded from Siberia to date (Mikhailov 2013). Among them, four species are known from Altai. One of them, C. talturaensis Logunov \& Marusik, 2000, is an endemic of Altai.
While studying newly collected material from Altai we found specimens of Chalcoscirtus that belong to an undescribed species very similar to C. grishkanae Marusik, 1988, which is known from upper reaches of the Kolyma River, environs of Magadan in Northeastern Siberia and from Transbaikalia (Logunov \& Marusik 2000). The goal of this paper is to provide a detailed morphological description and molecular evidence supporting species status of the population from Altai.

\section{Materials and methods}

\subsection{Morphology}

Specimens were photographed with a Canon EOS 7D camera attached to an Olympus SZX16 
stereomicroscope at the Zoological Museum, University of Turku, Finland. Digital images were combined using CombineZP image stacking software. Epigynes were cleared in a $\mathrm{KOH} /$ water solution until soft tissues were dissolved. Photographs were taken in dishes with paraffin on the bottom to hold the specimens in position. All measurements are given in millimeters. Leg segment lengths were measured on the dorsal side. Data on the spination is based on examination of one specimen of each species (one side of the body). The format of the descriptions and terminology follows Logunov and Marusik (1999).

\subsection{Phylogeny}

In order to check that the small differences in size, legs and abdominal patterns are not caused by intraspecific variation, molecular analyses were performed with specimens of four species from Altai: C. grishkanae, and C. ansobicus Andreeva, 1976 as well as two species from the related genus Euophrys C.L. Koch, 1834, namely E. flavoater (Grube, 1861) and E. frontalis (Walckenaer, 1802). Additionally, five species belonging to the same tribe, Euophryini, with $16 \mathrm{~S}$ sequences already available in GenBank were added to the dataset. These species were C. alpicola (L. Koch, 1876), C. infimus (Simon, 1868), E. frontalis, Pseudeuophrys erratica (Walckenaer, 1826) and Talavera minuta (Banks, 1895) (Table 1).

\subsubsection{Laboratory procedures}

A fragment of mitochondrial ribosomal $16 \mathrm{~S}$ rRNA was sequenced from two specimens belonging to the new species and three $C$. grishkanae specimens from Magadan. In addition, two C. ansobicus specimens, two E. flavoater and two E. frontalis specimens were sequenced. Euophrys was included since the genus is closely related to Chalcoscirtus (Prószyński 1976, Zhang \& Maddison 2013). The two studied Euophrys species differ in colour but have very similar copulatory organs as $C$. grishkanae and the new species described here.

The specimens were preserved in $96 \%$ ethanol and their DNA was extracted from legs using the NucleoSpin ${ }^{\circledR}$ Tissue kit (Macherey-Nagel) according to the manufacturer's protocol (incubating overnight). PCR amplifications were performed using MyTaq ${ }^{\mathrm{TM}}$ Red Mix (Bioline) using the primer pair $16 \mathrm{Sa} / 16 \mathrm{Sb}$ (Xiong \& Kocher 1991, Edgecombe et al. 2002). Each reaction included $0.25 \mu 1$ of both forward (16Sa: 5 '-CGC CTG TTT ATC AAA AAC AT-3') and reverse (16Sb: 5'-CTC CGG TTT GAA CTC AGA TCA-3') primers and $2 \mu 1$ of the template. The total volume per reaction was $12.5 \mu$. The amplification consisted of an initial denaturation step (1 min at $95^{\circ} \mathrm{C}$ ), followed by 35 cycles of denaturation $\left(15 \mathrm{~s}\right.$ at $\left.95{ }^{\circ} \mathrm{C}\right)$, annealing $\left(15 \mathrm{~s}\right.$ at $\left.43{ }^{\circ} \mathrm{C}\right)$, and extension $\left(10 \mathrm{~s}\right.$ at $\left.72{ }^{\circ} \mathrm{C}\right)$. The same protocol was used to amplify another mitochondrial marker, cytochrome c oxidase subunit I (COI) but it did not amplify successfully due to primer issues.

Visualization of the PCR products was done with $1 \%$ agarose gel electrophoresis with the Midori Green Advance DNA Stain and Fast Gene $^{\circledR}$ GelPic LED Box (Nippon Genetics, $\mathrm{GmbH})$. The samples were purified using ExoSAP-IT (Affymetrix). Sequencing was conducted at the Institute for Molecular Medicine Finland (FIMM). Forward and reverse sequences were assembled and their quality was checked using Sequencer 5.0.1 (Gene Codes Corp., Ann Arbor, Michigan, USA).

\subsubsection{Sequenced specimens}

The new sequences are deposited in GenBank (see Table 1 for the accession numbers).

Detailed collecting data of the specimens of the new species and C. grishkanae are given in sections 3.1. and 3.2., respectively, whereas those of other sequenced species are given below. General information of voucher specimens are in Table 1.

Chalcoscirtus ansobicus: Tajikistan: $2 \hat{\jmath}$, environs of Dushanbe, Hissar Mt. Ridge, $38^{\text {th }} \mathrm{km}$ of Varzob Hwy, Takob Gorge, environs of Dehmalik Vill., 3850.829’ N, 68 ${ }^{\circ} 54.637^{\prime} \mathrm{E}, 805$ m a.s.1., 8.V.2015, Y. M. Marusik \& M. Saidov leg.

Euophrys flavoater: Mongolia, Khovd Aimag: $1 \delta^{\lambda} 1$, Ikh-Khavtag-Uul Mt. Range, near Yargaityn-Sair Gorge $\left(45^{\circ} 03^{\prime} \mathrm{N}, \quad 92^{\circ} 09^{\prime} \mathrm{E}\right)$, mountain stony steppe with rocky outcrops, 
Table 1. List of species, voucher ID, countries and GenBank accession numbers for the specimens of Salticidae used in the phylogenetic analysis. Previously published sequences marked with *.

\begin{tabular}{llllll}
\hline Genus & Code & Species & Voucher & Country & 16S rRNA \\
\hline Chalcoscirtus & Cha1a & C. grishkanae & ISEA & Magadan area, Russia & MF149960 \\
& Cha1b & C. grishkanae & ISEA & Magadan area, Russia & MF149961 \\
& Cha1c & C. grishkanae & ISEA & Magadan area, Russia & MF149962 \\
& Cha2a & C. sinevi sp. n. & ISEA & Altai, Russia & MF149963 \\
& Cha2b & C. sinevi sp. n. & ISEA & Altai, Russia & MF149964 \\
& Cha3a & C. ansobicus & ZMMU & Tajikistan & MF149958 \\
& Cha3b & C. ansobicus & ZMMU & Tajikistan & MF149959 \\
& & C. alpicola & d294 & Canada & KC615864* \\
& & C. infimus & JXZ293 & Spain & KC615865* \\
Euophrys & Efla4a & E. flavoater & ISEA & Mongolia & MF149965 \\
& Efla4b & E. flavoater & ISEA & Mongolia & MF149966 \\
& Efro5a & E. frontalis & ZMMU & Tajikistan & MF149967 \\
& Efro5b & E. frontalis & ZMMU & Tajikistan & MF149968 \\
& & E. frontalis & JXZ137 & Germany & KC615960* \\
Pseudeuophrys & & P. erratica & JXZ194 & USA & KC616008* \\
Talavera & & T. minuta & JXZ202 & Canada & KC616019* \\
Anasaitis & & A. adorabilis & JXZ359 & Dominican Republic & KC615812* \\
& & & & &
\end{tabular}

1,900-2,150 m a.s.1., 30-31.V.2015, A. A. Fomichev leg.

Euophrys frontalis (black morph): Tajikistan: $1 \delta^{\lambda} 1$, env. of Dushanbe, Hissar Mt. Ridge, $48^{\text {th }}$ $\mathrm{km}$ of Varzob Hwy, 38 $55.531^{\prime} \mathrm{N}, 68^{\circ} 48.292^{\prime} \mathrm{E}$, 1,530 m a.s.1., S exposed slope with Juglans litter and under stones, 7.V.2015, Y. M. Marusik \& M. Saidov leg.

\subsubsection{Phylogenetic analysis}

Multiple sequence alignments were estimated with MUSCLE (Edgar 2004). The aligned 16S rRNA data consisted of altogether $447 \mathrm{bp}$. Parsimony analysis of the aligned data set was conducted with TNT (Tree Analysis using New Technology) version 1.5 (Goloboff et al. 2008). Anasaitis adorabilis Zhang \& Maddison, 2012 was chosen as the outgroup. The maximum number of trees in memory was set to 10,000 and gaps were treated as missing data. Nodal support (1,000 replicates) was estimated using parsimony jackknife (JF) resampling (Farris et al. 1996). Pairwise distances between the samples were calculated with MEGA: Molecular Evolutionary Genetics Analysis version 7.0 for bigger datasets (Kumar et al. 2016), version 7.0.21.

\subsection{Abbreviations}

Museums:

- ISEA, Institute of Systematics and Ecology of Animals, Siberian Branch of the Russian Academy of Sciences, Novosibirsk, Russia

- ZMMU, Zoological Museum of the Moscow State University

- ZMUT, Zoological Museum, University of Turku, Finland

Eyes: ALE, anterior lateral; AME, anterior median; PLE, posterior lateral; PME, posterior median.

Leg segments: Fe, femur; Mt, metatarsus; Pt, patella; Ta, tarsus; Ti, tibia.

Spination: $\mathrm{d}$, dorsal; $\mathrm{p}$, prolateral; $\mathrm{r}$, retrolateral; $\mathrm{v}$ ventral.

\section{Taxonomy}

\subsection{Chalcoscirtus sinevi sp. $\mathrm{n}$.}

Figs 1a,b, 2a-c, 3a-d, 4a,b, 5a-c, 6a,b

Type material. Holotype $\lesssim$ (ISEA 001.7950) and paratype + (ISEA 001.7951): Russia, Altai Republic, Kosh-Agach District, Chikhacheva Mt. 

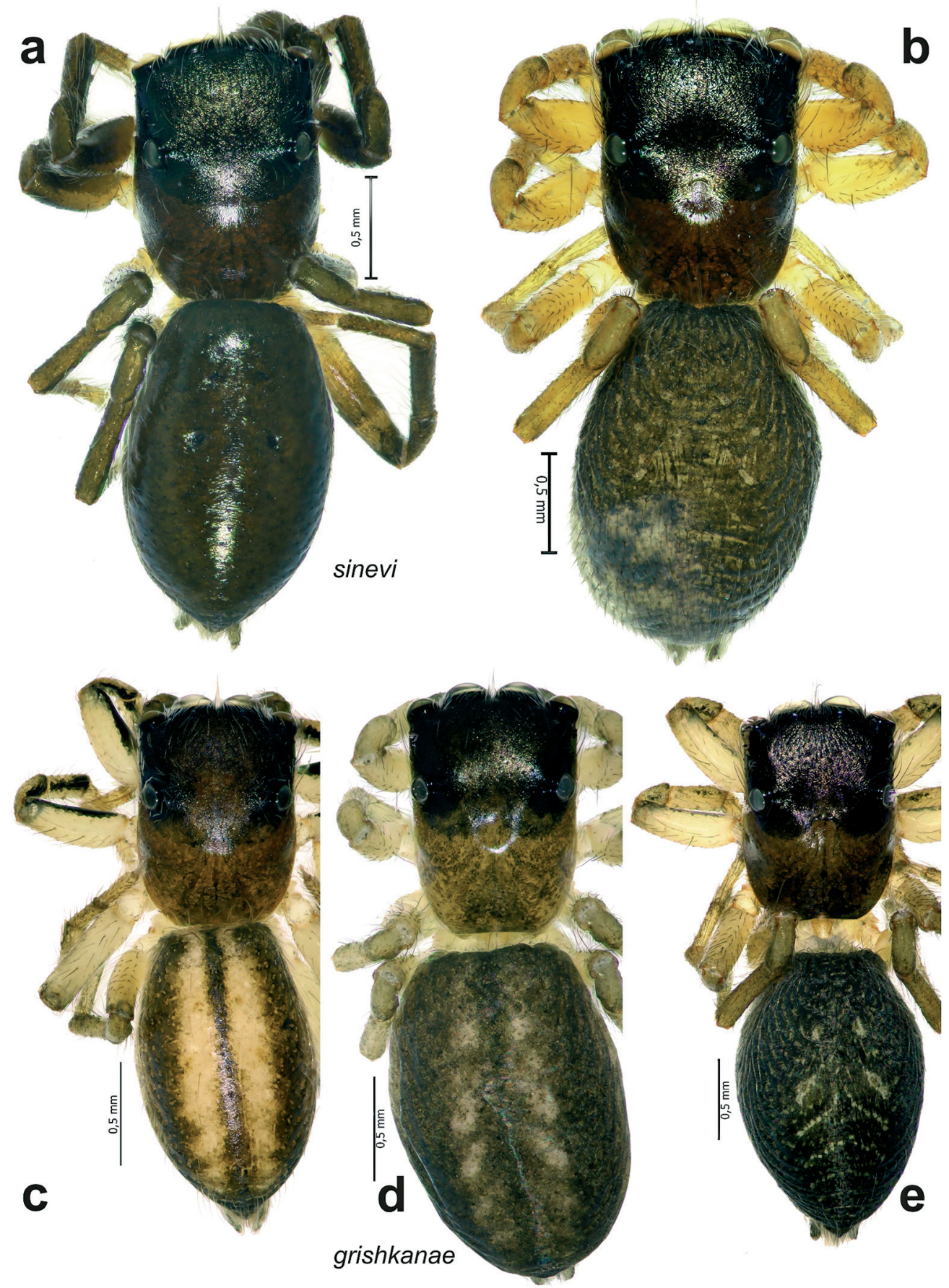

Fig. 1. Habitus of Chalcoscirtus sinevi sp. n. (a-b) and C. grishkanae (c-e). - a, c. Male. - b, d. Female. - e. Subadult female. Scale $=0.5 \mathrm{~mm}$.

Range, Talduair Massif, cirque near SW foothill of Talduair Mt., upper sources of Talduairy River, $49^{\circ} 58^{\prime} \mathrm{N}, 8^{\circ} 18^{\prime} \mathrm{E}$, moraine, $2,800 \mathrm{~m}, 1 . \mathrm{VII}$. 2014, A. A. Fomichev leg.
Diagnosis. The new species is morphologically very similar to $C$. grishkanae. Both sexes of the two species can be distinguished by the size and pattern. Chalcoscirtus sinevi sp. $\mathbf{n}$. is larger in 

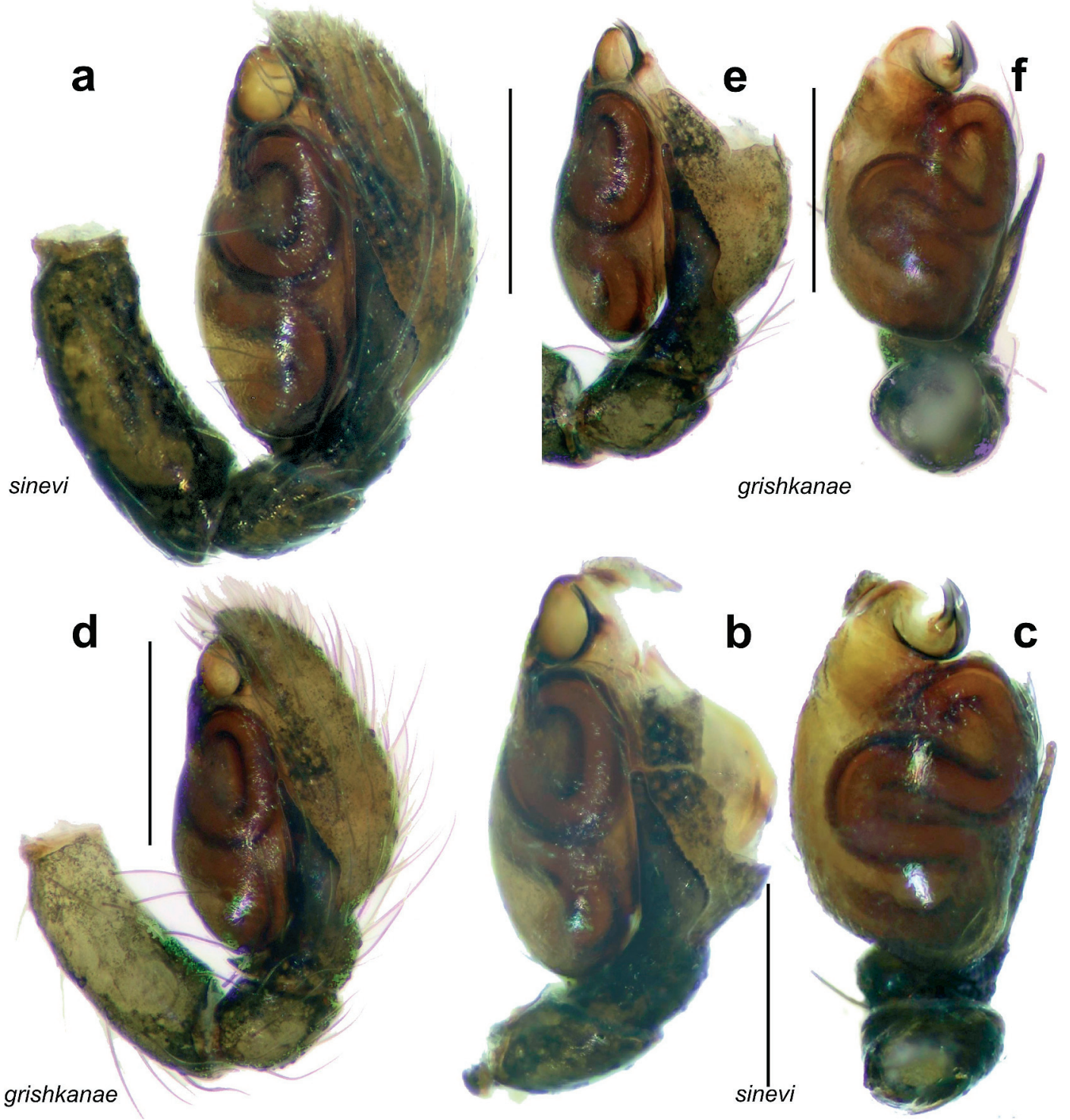

Fig. 2. Male palp of Chalcoscirtus sinevi sp. n. (a-c) and C. grishkanae (d-f). $-a$, d. Whole palp, retrolateral. $-b$, e. Terminal part, retrolateral, tip of cymbium removed. $-c$, f. Terminal part, ventral. Scale $=0.2 \mathrm{~mm}$.

size ( $₫$ carapace 1.35 vs 1.1 , 9 carapace 1.43 vs 1.15-1.4) and lacks the abdominal pattern. The male of the new species have a uniformly blackish abdomen, black femora-tibia of the legs I-II, while in C. grishkanae the abdomen is yellow with a thin dark median stripe and wide dark lateral bands, the femora-tibia I-II are yellow with a black prolateral stripe. The two species also differ by the spination of the tibia IV in both sexes: the new species lacks any spine, while $C$. grishkanae has 1 proventral spine. The male palps of the two species are very similar in shape and differ by size (cf. Figs 2-3) and the shape of the embolus: the new species has a relatively shorter free part of the embolus (cf. Figs 2c, 3a and $2 \mathrm{f}, 3 \mathrm{e}$ ). The female of the new species differs by the abdominal pattern, which is lacking in the new species and present in C. grishkanae (a series of yellowish spots along the median part of the abdomen). The epigynes of the two species are very similar. The new species has the copulatory openings closer to the anterior margin of the 


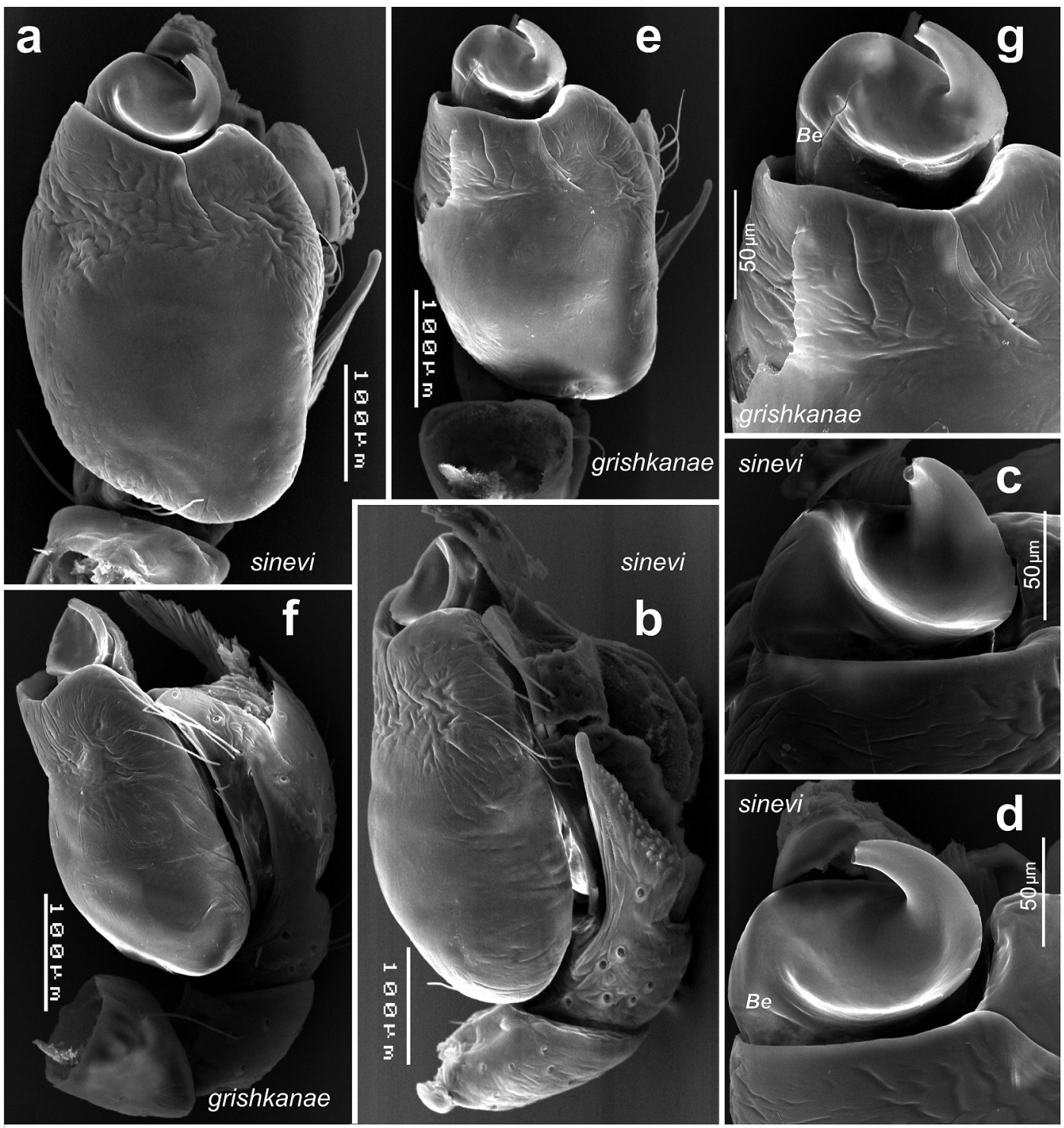

Fig. 3. SEM microphotographs of male palp of Chalcoscirtus sinevi sp. $\mathbf{n}$. (a-d) and C. grishkanae (e-g). - a, e . Palp, ventral. - b, f. Palp, retrolateral. - c. Embolus, ventro-prolateral. - d, g. Embolus, ventral. Scale: $a-b$, e-f = $0.1 \mathrm{~mm}$; $\mathrm{c}-\mathrm{d}, \mathrm{g}=0.05 \mathrm{~mm}$. Abbreviation: Be base of embolus.

fovea, while in C. grishkanae they are located in the middle. The epigynal fovea in the new species is relatively wider than in C. grishkanae (see Fig. $5 \mathrm{a}$ and $5 \mathrm{~d}$ ). The endogynes of the two species differ by the relative size and spacing of the copulatory ducts: in the new species, the copulatory ducts are spaced by about a diameter, but in $C$. grishkanae by 2 diameters (cf. Fig. 4a and 4c).

Description. Male. Total length 2.85. Carapace: 1.35 long, 0.9 wide, 0.63 high at PLE. Ocu- lar area 0.68 long, 0.88 wide anteriorly, and 0.83 wide posteriorly. Eye sizes: AME 0.29, ALE 0.19, PME 0.03, PLE 0.14. Abdomen: 1.63 long, 1.03 wide. Cheliceral length 0.38 . Clypeal height 0.07. Leg lengths as shown in Table $2 \mathrm{a}$, leg spination in Table 3a. Palp as in Figs 2a-c, 3a-d; tibial apophysis long, almost 2 times longer than tibia, dorsal edge saw-like; embolic part (embolus+base) wider than long; free part of embolus about 2 times shorter than whole embolic part. 


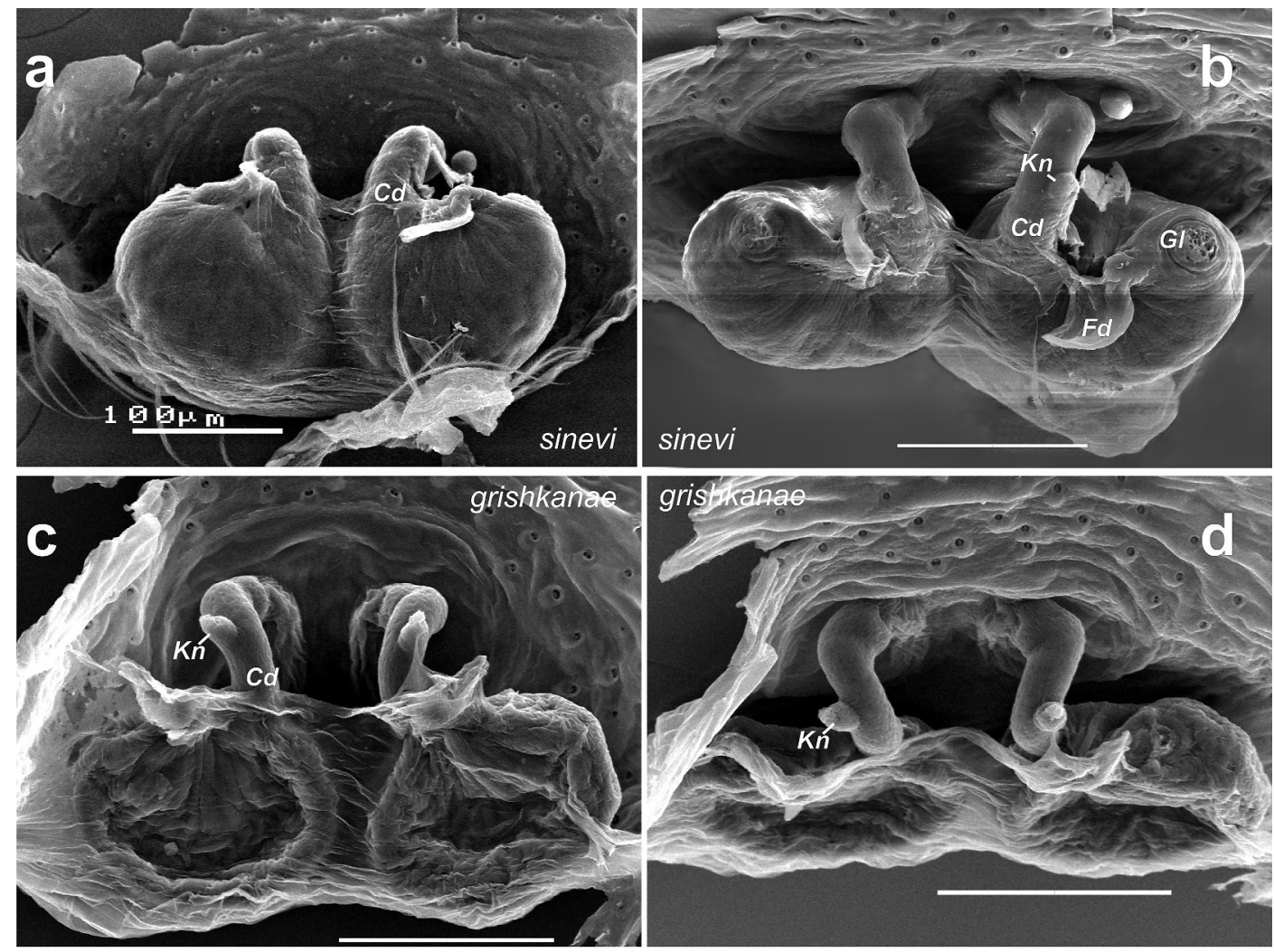

Fig. 4. SEM microphotographs of epigyne of Chalcoscirtus sinevi sp. n. (a-b) and C. grishkanae (c-d). - a, c. Dorsal. - b, d. Antero-dorsal. Scale $=0.1 \mathrm{~mm}$. Receptacles of C. grishkanae collapsed due to long exposure in $\mathrm{KOH}$ water solution. Abbreviations: $\mathrm{Cd}$ copulatory duct, $\mathrm{Fd}$ fertilization duct, $\mathrm{Gl}$ gland of receptacle, $\mathrm{Kn}$ knob-like extension of copulatory duct.

Colouration. Carapace dark brown almost black, lustrous. Eye field black, rest of carapace dark brown. AME and ALE surrounded by white hairs. Clypeus, chelicerae, labium, maxillae and sternum brown. Legs and palps black, shiny, femora II with dark-yellow median band; legs III and IV lighter than I, with almost yellow femora. Abdomen uniformly dark gray, almost black, glossy dorsally and light brown ventrally. Book lung covers light brown. Spinnerets gray.

Female. Total length 3.0. Carapace: 1.43 long, 0.98 wide, 0.58 high at PLE. Ocular area 0.7 long, 1.0 wide anteriorly, and 0.93 wide posteriorly. Eye sizes: AME 0.33, ALE 0.21, PME 0.04, PLE 0.17 . Abdomen: 1.7 long, 1.2 wide. Chelicera 0.3 long. Clypeus 0.06 high. Leg lengths as shown in Table $2 b$, leg spination in Table $3 b$. Epigyne as in Figs 4a-b, 5a-c, with oval, wider than long fovea, fovea divided by septum $(\mathrm{Se})$; copulatory openings $(\mathrm{Co})$ located close to anterior margin of fovea; receptacles oval, slightly wider than long, with a well developed gland $(G l)$; copulatory ducts $(C d)$ relatively short, about $1 / 2$ of receptacle width, runs anteriorly, and then bent posteroventrally, upper part of copulatory duct with knob-like extension $(K n)$, fertilization ducts $(F d)$ located between gland and copulatory duct.

Colouration. As in male, but legs dirty yellow, palps brown with yellow femora. Abdomen dark brown dorsally, cream-colored ventrally. Spinnerets light brown.

Etymology. The specific name is a patronym in honour of the well-known Russian entomologist, Sergei Yu. Sinev [=Sinyov] (Zoological Institute, St. Petersburg), who organized an expedition to Altai in which the new species was collected.

Habitat. Both the holotype and paratype were collected among stones in a kind of moraine (Fig. $6 b)$. 
Table 2. Leg measurements $(\mathrm{mm})$ of Chalcoscirtus sinevi sp. n. - a. Male. - b. Female.

\begin{tabular}{llllllll}
\hline & $\mathrm{Fe}$ & $\mathrm{Pt}$ & $\mathrm{Ti}$ & $\mathrm{Mt}$ & $\mathrm{Ta}$ & Total \\
\hline a. Male & & & & & & \\
I & 0.68 & 0.35 & 0.4 & 0.33 & 0.25 & 2.01 \\
II & 0.63 & 0.35 & 0.35 & 0.3 & 0.23 & 1.86 \\
III & 0.75 & 0.35 & 0.43 & 0.38 & 0.3 & 2.21 \\
IV & 0.8 & 0.33 & 0.53 & 0.45 & 0.3 & 2.41 \\
b. Female & & & & & & \\
I & 0.7 & 0.4 & 0.45 & 0.35 & 0.25 & 2.15 \\
II & 0.68 & 0.38 & 0.4 & 0.3 & 0.25 & 2.01 \\
III & 0.83 & 0.4 & 0.48 & 0.4 & 0.28 & 2.39 \\
IV & 0.93 & 0.4 & 0.65 & 0.5 & 0.3 & 2.78 \\
\hline
\end{tabular}

Distribution. Known only from the type locality (Fig. 6a).

\subsection{Chalcoscirtus grishkanae Marusik, 1988 Figs 1c-e, 2d-f, 3e-g, 4c-d, 5d-f, 6a}

Chalcoscirtus grishkanae Marusik, 1988: 1475, figs 4.1-5 ( $\left.\jmath^{\wedge}+\right)$.

Material. 10 2 † 2juv. (ZMMU): Russia, Magadan, Nagayevskaya Sopka, stony scree,
Table 3. Leg spination of Chalcoscirtus sinevi sp. $\mathbf{n}$. - a. Male. - b. Female.

\begin{tabular}{lll}
\hline \multicolumn{2}{c}{ Ti } & Mt \\
\hline a. Male & & \\
I & v1-2-2 & v2-2 \\
II & v1-1-1 & p0-1 v2-1 \\
III & p0-1-0 r0-1-0 v0-1-0 & p0-2 r0-2 v2-1 \\
IV & 0 & r0-1 v0-2 \\
& & \\
b. Female & & \\
I & v2-2-2 & v2-2 \\
II & v1-2-1 & p0-1 v2-1 \\
III & p0-1-0 r0-1-0 v0-1-0 & p0-2 r0-2 v1-1 \\
IV & 0 & p0-1 r0-1 v1-1
\end{tabular}

593'스, 15046’E, 100 m, 25.VI.2015, Y. M. Marusik leg.

Diagnosis. The male of $C$. grishkanae differs from that of the new species by having an abdominal pattern (yellow background, dark and thin median stripe and 2 lateral dark bands). The embolus of $C$. grishkanae is rather similar to that of C. brevicymbialis Wunderlich, 1980 (Logunov \& Marusik 1999: figs 28-29), although it has a shorter tibial apophysis and uniform colouration. Females also differ from the congeners by the pattern and the shape of the epigyne. The epigyne is

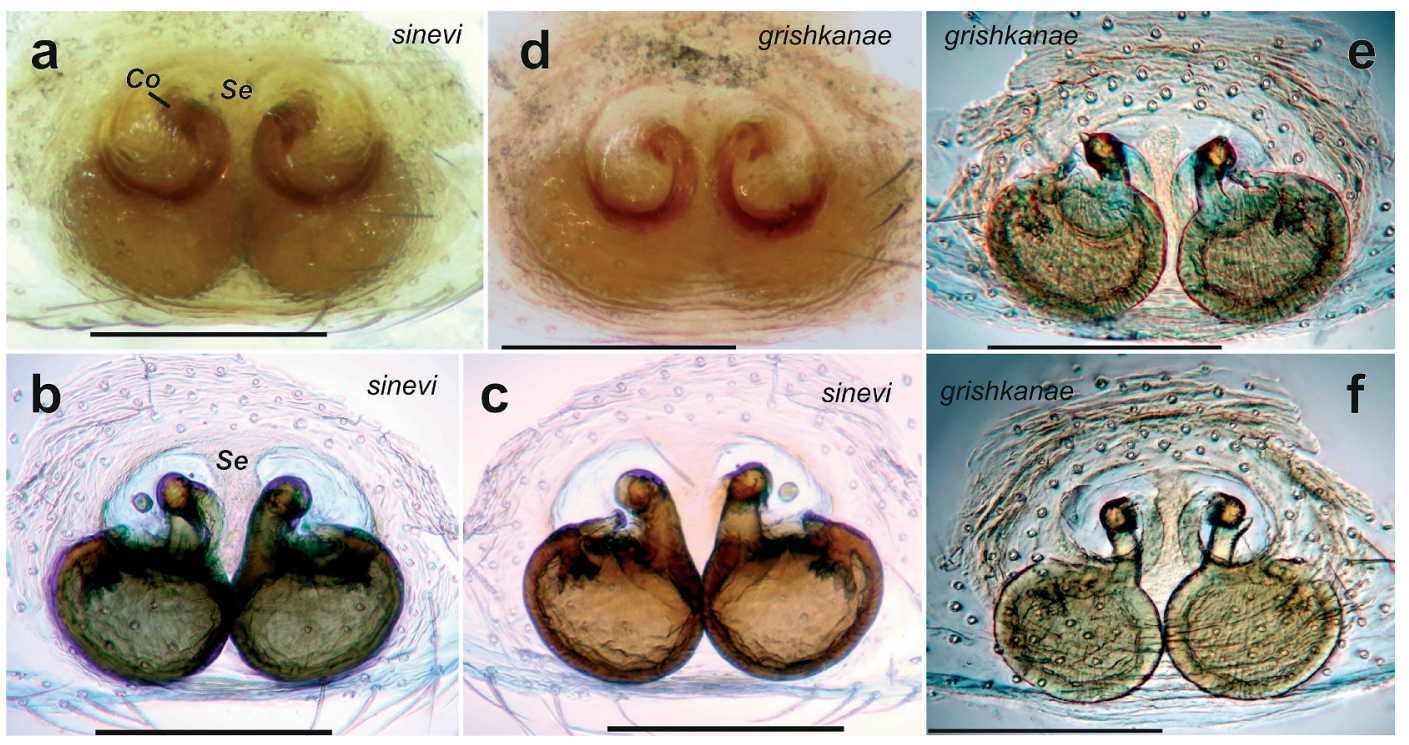

Fig. 5. Epigyne of Chalcoscirtus sinevi sp. n. (a-c) and C. grishkanae (d-f). - a, d. Intact, ventral. - b, f. After maceration, ventral. $-c$, e. After maceration, dorsal. Scale $=0.2 \mathrm{~mm}$. Abbreviations: Co copulatory opening, Se septum. 


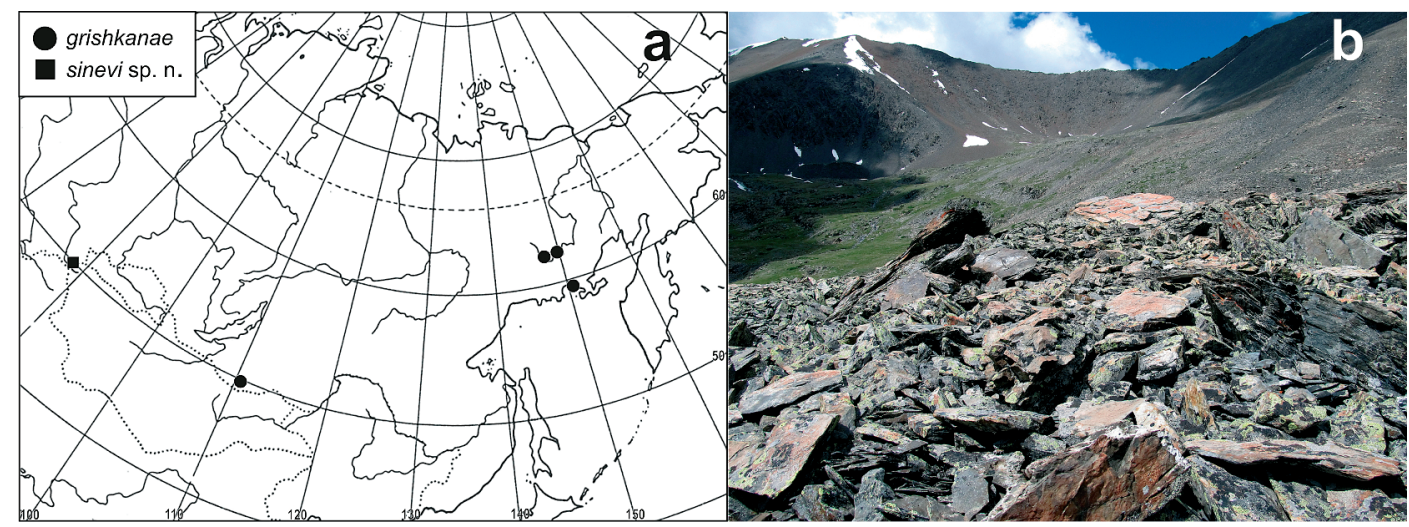

Fig. 6. - a. Distribution records of Chalcoscirtus sinevi sp. n. and C. grishkanae. - b. Habitat in which C. sinevi sp. $\mathbf{n}$. was collected.

somewhat similar to that in C. glacialis sibiricus Marusik, 1991, although C. grishkanae can easily be distinguished by the longer copulatory ducts and the presence of a septum, lacking in C. glacialis sibiricus.

Description. See Marusik (1988).

Comments. This species is known by a single taxonomical entry (see World Spider Catalog 2017). A general description can be found in Marusik (1988). Here we provide detailed SEM and digital photographs of the copulatory organs. The copulatory ducts have dorsal distinct knoblike extensions $(\mathrm{Kn})$ (Fig. 4d) not properly shown and not commented in Marusik (1988). The proventral spine on the tibia IV, a distinguishing character of C. grishkanae, is subject to variation. One female has no such spine, while one juvenile has a spine on one leg, but lacks one on the other side.

Fig. 7. Strict consensus of the two most parsimonious trees $(\mathrm{L}=212)$ based on 16S rRNA sequences of the new species, its close relatives and Anasaitis adorabilis as an outgroup. Jackknife resampling values $>50 \%$ shown at the nodes. Two $C$. sinevi sp. n. specimens (2a \& $2 b)$ shown in bold.
Habitat. The specimens used in this study as well as the type series have been collected among stony debris on south-exposed slopes.

Distribution. The species has been recorded in four localities situated far from each other: Kolyma River upper reaches (2 localities), environs of Magadan in Northeastern Siberia, and in Sokhondo Nature Reserve in southern Transbaikalia (Logunov \& Marusik 2000) (Fig. 6a).

\subsection{Molecular survey}

In addition to the morphological comparisons we conducted molecular studies to check if the two populations, located far from each other, can be considered as belonging to different species. The parsimony analysis resulted in two most parsimonious trees of the length of 212 steps (see Fig. 7 
for strict consensus). In this tree, the Chalcoscirtus specimens form a monophyletic clade with a strong nodal support (JF 99). Chalcoscirtus sinevi sp. n. forms a separate, well-supported (JF 85) sister clade to C. grishkanae (JF 93). Evolutionary affinities between $C$. sinevi sp. n., C. grishkanae, C. ansobicus, C. alpicola and $C$. infimus remain unresolved in the strict consensus tree but are also beyond the purpose of this study.

The pairwise distance between $C$. sinevi sp. $\mathbf{n}$. and $C$. grishkanae is $1.3 \%$, equaling in total five nucleotide substitutions between the two species. The pairwise distance between $C$. sinevi sp. n. and $C$. ansobicus is $3.9 \%$. The results show that C. sinevi sp. n. forms its own evolutionary lineage separate to that of $C$. grishkanae and can therefore be considered a separate species closely related to $C$. grishkanae.

It is worth noting that although the copulatory organs of the two studied Euophrys species included in the analysis are indistinguishable in shape, they differ in colour pattern. The copulatory organs of E. frontalis from Tajikistan (black morph) and that from Germany (light morph) are also identical, but their 16S rRNA fragments differ by 3 substitutions (in an overlapping area of 189 bps).

Acknowledgements. We are grateful to Roman V. Yakovlev (Barnaul, Russia), Sergei Yu. Sinev (Saint Petersburg, Russia) and Alexey V. Pershin (Biysk, Russia) for organising the field trip to Altai in which the material treated here was collected. Y. Y. M. and A. A. F. wish to thank Seppo Koponen (University of Turku) for his hospitality and for arranging the visits to ZMUT. We are grateful to Tapani Hopkins for kindly checking the language. Two anonymous reviewers are acknowledged for their comments improving the manuscript. This study was supported in part by the grant No. 6.2884.2017/4.6 given by the Ministry of Education and Science of the Russian Federation.

\section{References}

Cutler, B. 1990: A revision of the western hemisphere Chalcoscirtus (Araneae: Salticidae). - Bulletin of the British Arachnological Society 8(4): 105-108.

Edgar, R. C. 2004: MUSCLE: multiple sequence alignment with high accuracy and high throughput. Nucleic Acids Research 32(5): 1792-1797.
Edgecombe, G. D., Giribet, G. \& Wheeler, W. C. 2002: Phylogeny of Henicopidae (Chilopoda: Lithobiomorpha): a combined analysis of morphology and five molecular loci. - Systematic Entomology 27: 31-64.

Edwards, G. B. 2003: A review of the Nearctic jumping spiders (Araneae: Salticidae) of the subfamily Euophryinae north of Mexico. - Insecta Mundi 16(1-3): 65-75.

Farris, J. S., Albert, V. A., Kllersjö, M., Lipscomb, D. \& Kluge, A. G. 1996: Parsimony jackknifing outperforms neighbor-joining. —Cladistics 12: 99-124. doi: 10.1111/j.1096 0031.1996.tb00196.x

Goloboff, P., Farris. J. \& Nixon, K. 2008: TNT, a free program for phylogenetic analysis. - Cladistics 24(5): 774-786. DOI: 10.1111/j.1096-0031.2008.00217.x

Kumar, S., Stecher, G. \& Tamura, K. 2016: MEGA7: Molecular Evolutionary Genetics Analysis version 7.0 for bigger datasets. - Molecular Biology and Evolution 33: $1870-1874$.

Logunov, D. V. \& Marusik, Y. M. 1999: A brief review of the genus Chalcoscirtus Bertkau, 1880 in the faunas of Central Asia and the Caucasus (Aranei: Salticidae). Arthropoda Selecta 7(3): 205-226.

Logunov, D. V. \& Marusik, Y. M. 2000: Catalogue of the jumping spiders of northern Asia (Arachnida, Araneae, Salticidae). - KMK Scientific Press Ltd., Moscow. 299 pp.

Marusik, Y. M. 1988: New species of spiders (Aranei) from the Upper Kolyma. - Zoologicheski Zhurnal 67(10): 1469-1482. [In Russian.]

Marusik, Y. M. 1990: Spider genus Chalcoscirtus (Aranei, Salticidae) from the USSR: Communication 1. - Zoologicheski Zhurnal 69(6): 45-57. [In Russian.]

Marusik, Y. M. 1991a: Spider genus Chalcoscirtus (Aranei, Salticidae) from the USSR. Communication 2. Zoologicheski Zhurnal 70(1): 19-31. [In Russian.]

Marusik, Y. M. 1991b: Spider genus Chalcoscirtus (Aranei, Salticidae) from the USSR. Communication 3. Zoologicheski Zhurnal 70(2): 22-29. [In Russian.]

Mikhailov, K. G. 2013: The spiders (Arachnida: Aranei) of Russia and adjacent countries: a non-annoteted checklist. - Arthropoda Selecta. Supplement No.3.262 pp.

Prószyński, J. 1976: Studium systematyczno-zoogeograflczne nad rodziną Salticidae (Aranei) Regionów Palearktycznego i Nearktycznego. - Wyžsza Szkoła Pedagogiczna w Siedlcach 6: 1-260. [In Polish.]

World Spider Catalog 2017: World Spider Catalog. - Natural History Museum Bern. Online at http://wsc. nmbe.ch, version 18.0. (Accessed on 10 January, 2017.)

Xiong, B. \& Kocher, T. D. 1991: Comparison of mitochondrial DNA sequences of seven morphospecies of black flies (Diptera: Simuliidae). — Genome 34: 306-311.

Zhang, J.-X. \& Maddison, W. P. 2013: Molecular phylogeny, divergence times and biogeography of spiders of the subfamily Euophryinae (Araneae: Salticidae). Molecular Phylogenetics and Evolution 68(1): 81-92. 